UNTAG Law Review (ULREV)

Volume 4, Issue 1, May 2020, PP 20 - 33

ISSN 2549-4910 (online) \& ISSN 2579-5279 (print)

http://jurnal.untagsmg.ac.id/indeks.php/ulrev/indeks

www.fakhukum.untagsmg.ac.id

\title{
CONTROLLING OF IMPORTED OR EXPORTED GOODS RELATED TO BRAND PROTECTION BY CUSTOMS
}

\author{
${ }^{1}$ Muchtar Anshary Hamid Labetubun, ${ }^{2}$ Marselo Valentino Geovani Pariela \\ ${ }^{1,2}$ Faculty of Law Pattimura University, Ambon, Indonesia \\ '1mahlabetubun@gmail.com \\ 르라iela@gmail.com
}

\begin{abstract}
Customs regulations in Indonesia, there is also a legal mechanism to protect brands. Provisions in Chapter X of Law, Number 10 of 1995 concerning Customs as amended by Act Number 17 of 2006 concerning Amendments to Law Number 10 of 1995 concerning Customs, includes a prohibition on import or export restrictions and controls on the import and export of goods the results of infringement of Intellectual Property Rights including Trademark Rights.

The role of Customs in the framework of protecting registered brands is as a traffic surveillance apparatus for goods entering or leaving Indonesian territory, the Directorate General of Customs and Excise (DJBC) is required to control the import-export of products resulting from violations in the field of trademark rights, and intellectual property rights and by court order can stop the entry and exit of goods infringing trademark rights. The implementation of the trips agreement in the laws and regulations on Indonesian customs can contribute to the protection of registered trademarks, especially in terms of being the front door in overcoming violations of trademark rights in Indonesia.
\end{abstract}

Keywords: Import-Export Control; Trademark Protection; Customs

\section{INTRODUCTION}

In the era of free trade, the influx of goods from abroad into Indonesia's customs territory is unavoidable. Because of a large number of products using foreign trademarks circulating in Indonesia, international trademarks must be identifiable. ${ }^{1}$ Registration of a trademark is used to identify goods and services produced or distributed by a particular company by giving the company the right to use the trademark exclusively, and the company has the right to prevent the use of unauthorized trademarks. Building relationships between products and businesses creates a valuable reputation or "good will," and this is the basis of most international trade. ${ }^{2}$

Trademarks are an essential part of IPR law. The brand is an industrial property that includes intellectual property. In general, a brand can be a name, word, logo, symbol, design, color, image, or a combination of two or more of these elements. The brand is essential in the business world.

1 Julius Rizaldi, Perlindungan Kemasan Produk Merek Terkenal Terhadap Persainga Curang, Alumni, Bandung, 2009, p.3

2 Tim Lindsey, Eddy damian, dkk, Hak Kekayaan Intelektual Suatu Pengantar, Asian Law Group Pty Ltd dan Alumni, Bandung, 2002, p. 132 
As part of the intellectual property rights law, a trademark will clearly be protected in its use and use, in order to protect a trademark, the trademark must first be registered. Registration is important to get the rights to the mark. Trademark rights are exclusive rights granted by the state to trademark owners registered in the "public register of trademarks" for a certain period of time.

A trademark can be accepted if it fulfills the conditions specified in the Act. Based on Article 20 of Law Number 20 the Year 2016 Regarding Trademark and Geographical Indications, that:

"Trademarks cannot be registered if:

a) contrary to state ideology, statutory regulations, morality, religion, decency, or public order;

b) the same as, relating to, or only mentioning the goods and services for which registration is requested;

c) contains elements that can mislead the public about the origin, quality, type, size, type, the purpose of use of the goods and services being applied for registration or constitute the name of the protected plant variety for similar goods and services;

d) contains information that is not in accordance with the quality, benefits, or efficacy of the goods and services produced;

e) has no distinguishing features; and

f) is a public name and symbol of public property".

In addition, the registration of a mark is also rejected if it has similarity in principle or in whole with a mark that is already well-known to someone else who has already been registered in advance for goods or services that are similar or not of the same type, as contained in Article 21 Paragraph (1) of the Law -Grands and Geographical Indications, that:

"An application is rejected if the Mark has similarities in principle or in whole with:

a) Trademarks are registered with other parties or have been previously applied for by other parties for similar goods and services;

b) Other parties' famous brands for similar products and services;

c) Other parties' well-known brands for products and services that do not meet the specific requirements; or

d) Registered Geographical Indications ".

Trademark is a tool to distinguish goods and services produced by a company with the intention to show the characteristics and origin (the indication of origin) of goods or services, which are also a differentiator for other products and services ${ }^{3}$ Giving the brand of goods and services will affect the image of a company in the eyes of consumers, or it can be said will increase the company's image. ${ }^{4}$ Giving this brand will also provide quality (quality) of these goods and services and prevent imitation. In this case, the brand provides the value or quality of the products and services concerned. This is not only useful for the producers of the brands but also provides guarantees and quality protection of products and services to consumers. ${ }^{5}$

3 Ibid,p. 152

4 Haris Munandar, Mengenal HaKI, Hak Cipta Paten dan Merek Serta Seluk Beluknya, Erlangga, Jakarta, 2008 , p. 52

$5 \mathrm{Ibid}, \mathrm{p} .153$ 
Using a famous brand is a matter of pride for consumers, especially if the brand of goods is an original product that is difficult to obtain. A person's prestige sometimes lies in the goods and or services used for reasons of quality, reliability, or investment so that the use of a well-known brand becomes a lifestyle. Brands can also make someone confident or even determine their social status. It is essential to protect ownership of brands because certain brands of goods and or services in the era of free trade can cross borders between countries. ${ }^{6}$

Trademark is very important as a sign of ownership of goods and or services in national and international trade traffic. ${ }^{7}$ Because a brand can gain commercial profit, and a brand can also make the prices of a product expensive even more valuable than the company that produces it, ${ }^{8}$ Then other parties are also trying to imitate brands that have long been famous in the community.

Even though the right to a registered mark has an exclusive right to prohibit third parties without the permission and knowledge of the registered trademark owner to use a target which has the same principle in principle for goods and or services that have been registered in advance. ${ }^{9}$ However, it could be that another party mimics an existing mark or registers a trademark that has similarities in principle with a registered brand first.

Customs regulations in Indonesia also contain legal mechanisms to protect brands. Provisions in Chapter X of Law Number 10 of 1995 concerning Customs as amended by Act Number 17 of 2006 concerning Amendments to Law Number 10 of 1995 concerning Customs (hereinafter referred to as Customs Law), contains restrictions on import or export restrictions and controlling the import and export of goods resulting from violations of Intellectual Property Rights (hereinafter abbreviated as IPR) including trademark rights. The Directorate General of Customs and Excise carries out customs duties in the form of everything related to the supervision of the traffic of goods entering or leaving the customs area and collecting import duties.

The owner or holder of Intellectual Property Rights can ask the local District Court to issue a written order addressed to Customs and Excise officials to temporarily suspend the release of imported or exported goods from the Customs Area which, based on sufficient evidence, is allegedly the result of trademark infringement and protected copyright in Indonesia.

Based on the description above, regarding the protection of trademark rights, there is not only a monopoly by the Directorate General of IPR of the Indonesian Ministry of Law, as well as other law enforcement officers but also based on the provisions of Article 54 of the Customs Law, it also covers the customs law area in terms of anticipating the entry of goods indicated by the results infringement in the field of intellectual property especially brand rights.

6 Sudargo Gautama dan Rizwanto Winata, Pembaharuan Hukum Merek Indonesia (Dalam rangka WTO, TRIPS), Citra Aditya Bakti, Bandung, 1997, p. 5-6.

7 Dwi Rezki Sri Astarini, Penghapusan Merek Terdaftar, Alumni, Bandung, 2009, p. 1.

8 Eddy Damian, Hak Kekayaan Intelektual (SuatuPengantar), Alumni, Bandung, 2003, p. 131

9 Sudargo Gautama, Hak Merek Dagang Menurut Perjanjian TRIPs-GATT dan Undang-Undang Merek RI, Citra Aditya Bakti, Bandung, 1994, p. 19. 
The Customs Law explains that the identification of trademark protection actions through customs is owned by the owner or holder of the trademark rights. Without the request of the owner or holder of the trademark right, identification of the role of customs cannot be made, because of the customs apparatus, according to Article 54 of the Customs Law takes action after an application from the owner and holder of the trademark right. This provision is a weakness of the Customs Law for violating the protection of trademark rights. It was said so because the order to suspend the entry of goods suspected of violating the trademark rights must be done in writing and signed by the Chairman of the Commercial Court.

This condition is very risky if the owner or holder of the brand carries out the order, of course, it will take time and time, and on the one hand, the goods or products that are the result of the violation of the brand have already been freed from customs supervision. The law can be simpler in the study, so it does not require identification from the Chair of the Commercial Court, just identification and evidence from the trademark owner. Another thing that is a weakness of the Customs Law is a mark that can be protected by Customs is a registered trademark.

In Indonesia, there are a lot of counterfeit goods. Counterfeit goods can occur by faking brands and goods at the same time, or only goods that are directly marketed to the public, such as the case of the circulation of plastic rice from China, which horrified the public some time ago.

From 2012 to 2013, the Ministry of Trade (Ministry of Trade) has handled 726 cases of circulating goods that are not in accordance with regulations or are illegal. Some of the products secured by the Ministry of Trade are fake. Hundreds of violations of the circulation of goods involve many parties, both individuals and companies. Illegal goods that dominate are electronics, household appliances, and automotive spare parts.Imported goods also do not escape forgery. The Agency for Drug and Food Control (BPOM) frequently destroys illegal drugs, cosmetics, and food by falsifying goods and packaging and well-known brands. From 2009 to 2011, BPOM was recorded as having succeeded in destroying illegally imported products worth Rp. 2 billion.

The above case is a small example; of course, many other brand violations occur. The case may be possible originating from imported products that can also occur counterfeiting both goods and brands. Therefore, it is essential to monitor imported goods entering through the Indonesian door by checking the brand or the authenticity of the goods. In this situation, the role of the Customs in overseeing the entry of counterfeit and pirated goods is very important,

10 Isu Plastik, Beras Organik Kini Diburu Warga, Liputan 6, 30 Mei 2015, http://tv.liputan6.com/read/2242573/isu-plastik-beras-organik-kini-diburu-warga,Accessed 30 October 2019.

11 Kemdag Tertibkan 726 Jenis Barang Ilegal, Suara Pembaharuan, 23 April 2013, http://sp.beritasatu.com/ekonomidanbisnis/kemdag-tertibkan-726-jenis-barang-ilegal/34399. Accessed 30 October 2019.

12 Produk Ilegal Datang Dari China \& Malaysia BPOM Tangani 51 Kasus, Hukuman Tak Bikin Jera, 30 September 2012, http://www.rmol.co/read/2012/09/30/79937/Produk-Ilegal-Datang-Dari-China-\&Malaysia-, Accessed 30 October 2019. 
because Customs officials have the authority to take action to stop the import or export activities temporarily. The authority to take this action can be exercised if there is sufficient initial evidence of goods suspected of infringing trademark.

\section{PROBLEM}

Based on the introductory description above, the writer is interested in studying the problem in this article, namely how the role of customs in controlling the import or export of goods related to brand protection?

\section{DISCUSSION}

\section{Protection of Trademarks in Customs Law}

Protection of trademarks in the Customs Law only concerns issues of protection over the control of imports or exports of violated goods. This means that the Customs Law can contribute to the implementation of protection of brand rights in the capacity of the scope and duties of customs only in the field of exports and imports only. The concept given is customs is responsible for goods entering and leaving Indonesian territory. With this concept, customs benefits will be obtained in the form of control over the entry or exit of products that conflict with brand rights.

The several provisions and procedures for the protection of trademarks in the Customs Law include the provisions as regulated in Law Number 17 of 2006 concerning Amendments to Law Number 10 of 1995 concerning Customs in the following articles:

Article 54:

" At the request of the owner or holder of trademark or copyright rights, the head of the commercial court may issue a written order to Customs and Excise officials to temporarily suspend the release of imported or exported goods from customs areas which, based on sufficient evidence, are allegedly the result of trademark and rights violations. Copyright protected in Indonesia".

Article 54 above explains the role of the Chairperson of the Commercial Court, who can give orders to Customs and Excise officials to temporarily suspend the release of imported or exported goods at the request of the owner or holder of the trademark rights. The request must be preceded with sufficient evidence of violations of trademark rights or other rights protected by law.

The written order will provide a suspension order on the release of imported and exported goods as regulated in Article 56 below:

Article 56:

"Based on written instructions as referred to in Article 54, customs and excise officials:

a) Notifying the importer, exporter or owner of goods in writing of an order to suspend the release of imported and exported goods; 
b) Carry out the postponement of the relevant import or export goods release from the customs area as from the date of receipt of the written order of the head of the commercial court.

Article 56 above clearly explains that the order of the head of the court is notified and implements the suspension of the detention of goods that are allegedly the result of the violation of trademarks and protected copyrights in Indonesia as of the date of receipt of the written order of the head of the commercial court.

\section{Article 57:}

(1) The suspension of the release of goods, as referred to in Article 56, letter b is carried out for a maximum period of 10 (ten) working days.

(2) The period of time, as referred to in paragraph (1), based on the reasons and with certain conditions, can be extended once for a maximum of 10 (ten) working days with the written order of the head of the commercial court.

(3) The extension of the suspension of the release of imported or exported goods, as intended in paragraph (2) is accompanied by an extension of the guarantee as referred to in Article 55 letter d.

The suspension of detention referred to in Article 57 above is carried out for a maximum of 10 working days and can be extended by another 10 working days and by order of the head of the court.

Article 58:

(1) At the request of the owner or right-holder of a trademark or copyright requesting a suspension order, the head of the commercial court may give permission to the owner or right-holder to inspect the imported or exported goods for which the expenditure is suspended.

(2) The granting of an examination permit as referred to in paragraph (1) shall be carried out by the head of the commercial court after listening to and considering explanations and taking into account the interests of the owner of the imported or exported goods whose suspension is requested.

Article 58 above explains the owner or holder of the trademark right can inspect the imported or exported goods.

Article 59:

(1) If within 10 (ten) working days as referred to in Article 57 Paragraph (1), Customs and Excise officials do not receive notification from the party requesting the suspension of expenditure that legal action is needed to maintain their rights in accordance with statutory regulations in force has been carried out, and the head of the commercial court does not extend in writing the suspension order, Customs and Excise officials are obliged to end the deferral of the relevant import or export goods and settle them in accordance with customs provisions under this Law. 
(2) In the event that legal action to defend rights has been carried out in accordance with the applicable laws and regulations within 10 (ten) working days as referred to in paragraph (1), the party requesting the suspension of the release of imported or exported goods must paragraph (1), the party requesting the suspension of the release of imported or exported goods must immediately report them to Customs and Excise officials who receive orders and carry out the suspension of imported or exported goods.

(3) In the event that the legal action as referred to in Paragraph (2) has been notified, and the head of the commercial court has not extended in writing the suspension order as referred to in Article 57 Paragraph (2), the Customs and Excise official will end the suspension of issuing the relevant imported or exported goods. And resolve them in accordance with customs provisions based on this Law.

Article 59 above explains that if Customs and Excise officials do not receive notification from the party requesting the suspension of expenditure that the legal actions necessary to maintain their rights in accordance with applicable laws and regulations have been carried out and the head of the commercial court does not extend the written suspension order.

Article 60:

"In certain circumstances, importers, exporters, or owners of imported or exported goods may submit a request to the head of the commercial court to order in writing the Customs and Excise officials to end the suspension as referred to in Article 54 by submitting the same guarantee as referred to in Article 55 letter d".

Article 60 explains the termination of the proposal by the importer, exporter, or owner of the imported or export goods being terminated to the head of the commercial court.

Article 61:

(1) If from the results of the case inspection it is proven that the imported or exported goods do not constitute or do not originate from the result of a trademark or copyright violation, the owner of the imported or exported goods is entitled to obtain compensation from the owner or right holder who requests the suspension of the release of imported goods or the export.

(2) The commercial court examining and deciding the case as referred to in paragraph (1) may order that the guarantee referred to in Article 55 letter $\mathrm{d}$ be used as payment or as part of compensation payment to be paid.

While other provisions relating to the protection procedures for trademarks in the Customs Law areas contained in several articles as follows:

Article 55:

"The request referred to in Article 54 is submitted accompanied by:

a. Sufficient evidence of a violation of the mark or copyright in question; 
b. Proof of ownership of the mark or copyright in question; details and clear information about imported or exported goods for which the suspension of expenditure is requested so that they can be recognized quickly by the Customs and Excise Official; and guarantee".

The act of suspending the release of imported or exported goods may also be carried out because of a position by the Customs and Excise Official if there is sufficient evidence that the goods constitute or originate from the result of a trademark or copyright violation.

Article 63:

"Provisions on the suspension of the release of goods which are suspected to be the result of the infringement of intellectual property rights are not enforced on luggage of passengers, the crew of transport facilities, border crossers, or items sent by post or entrusted services not intended for commercial purposes".

Goods suspected of being the result of the infringement of intellectual property rights may be suspended for entry into Indonesia, passenger luggage or non-commercial goods may not be subject to suspension of entry into Indonesia.

\section{Article 64:}

(1) Control of import or export of goods which are allegedly the result of the infringement of intellectual property rights, other than trademarks and copyrights as provided for in this law, shall be determined by Government Regulation.

(2) Further provisions needed for the implementation of Article 54 to Article 63 shall be regulated by Government Regulation.

Article 64 above is an article that explains the control over the control of imports or exports of goods suspected of being the result of the infringement of intellectual property rights, in addition to trademarks and copyrights as provided for in this law, stipulated by Government Regulation. Sanctions Against Violation of Registered Trademarks The existence of Law Number 15, the Year 2001, is basically intended to anticipate the increasingly widespread forms of trademark infringement. Likewise with the use of trademarks by unauthorized parties, then as explained earlier that Law Number 15 of 2001 in addition to containing criminal provisions against violations of trademark rights, also legitimate trademark owners can file lawsuits against parties who use their trademarks illegally as stated in Article 76 of Law Number 15 the Year 2001.

Article 76 of Law Number 15 the Year 2001 reads:

(1) The owner of a registered mark may file a lawsuit against another party who without the right to use the mark has the same principle in principle or in whole for similar goods or services:

a. Complaint suit, and

b. Termination of all acts related to the use of the mark.

(2) The claim as referred to in paragraph (1) shall be submitted to the Commercial Court. 
From the above article, it can be seen that if a lawsuit must be filed against another party without the right to use a trademark which is principally similar or in whole for similar goods or services, a claim for compensation may be added or only with a cessation order for all acts of use concerned brand. So the unauthorized use of unauthorized seizure or piggybacking on a mark by a party cannot be filed against it and submitted to the Commercial Court. In accordance with what was witnessed in the renewal system of intellectual property rights today.

\section{The Role of Customs as a Border Agency Against Brand Protection}

Customs play an essential role in monitoring the traffic of goods entering or exiting customs areas, particularly in relation to IPR protection efforts to prevent the entry of goods that violate trademark rights. ${ }^{13}$ In recent years, efforts to implement the protection of brand rights as adequate intellectual property rights protection have been increasing, both among industry, the wider community, and the government. This happens, along with the growing role of brand rights in several fields of economic activity, and the increasing violation of brand rights. Increased protection of trademark rights is considered as a very important thing in the framework of international trade. The importance of increasing IPR protection is due to several things, namely: ${ }^{14}$

1) The role of IPR-based products in trade (especially in international trade) has increased sharply;

2) Advances in communication and international relations have created a global market;

3) The development of technology is relatively inexpensive and not too cheap and not too complex, to reproduce certain types of goods;

4) Increased research and development in creating new products;

5) Some aspects of the new technology have not been able to enter precisely in one type of IPR protection.

Protection of trademark rights as IPR is a commitment that must be fulfilled as a consequence of Indonesia becoming a member of the World Trade Organization (WTO) by signing the Marrakech, Morocco agreement in 1994 which was ratified through Law Number 7 of 1994 concerning the Establishing World Trade Organization in which also includes Trade Related Aspects of Intellectual Property Rights (TRIPs) agreements. ${ }^{15}$

The TRIPs Agreement contains strict IPR norms and standards that aim to: ${ }^{16}$

1) Increasing protection of IPR from traded products;

2) Guarantee the procedures for implementing IPR that do not hamper trading activities;

3) Formulate rules and discipline regarding the implementation of protection of IPR;

13 Edi Santoso, Penegakan Hukum terhadap Pelanggarang Merek Dagang Terkenal Melalui Perang Kepabeanan sebagai Upaya Menjaga Keamanan dan Kedaulatan Negara, Jurnal Rechts Vinding, Volume. 5, Number 1, April 2016.p. 129.

14 Direktorat Jenderal Bea dan Cukai, "Peranan Bea dan Cukai Dalam Perlindungan Hak atas Kekayaan Intelektual," Paper presented at Training Course on Intellectual Property Rights, Jakarta, 24-28 Mei 2004), p. 2-3.

15 Djuhaendah Hasan, Lembaga Jaminan Kebendaan Bagi Tanah dan Benda Lain Yang Melekat Pada Tanah Dalam Konsepsi Penerapan Asas Pemisahan Horisontal, Citra Aditya Bakti, Bandung,1996, p. 43. 16 Ibid., p. 44 
4) Developing the principles, practices, and mechanisms of international cooperation to deal with the trade in counterfeit goods or piracy of IPRs.

Prior to the entry into force of the TRIPs agreement, customs institutions in various countries generally were not much involved in the protection of IPR, with increasing international trade and increasingly widespread IPR violations that crossed national borders, the importance of the role played by customs in carrying out protection IPR. Therefore, TRIPs specifically regulates the provisions on "border measure control/border enforcement," namely supervision by the Customs (Customs Administration) of goods resulting from IPR violations. With these provisions, then in each country, border cross control apparatus in this case customs institutions (in Indonesia is the Directorate General of Customs and Excise), must be involved in the implementation of IPR protection including trademark rights.

Protection of intellectual property needs to get a priority scale of handling by DJBC officials in the field. This is closely related to state revenues from the indirect tax sector in the form of import duties in the context of contributing to the country's finances at this time and in the future. ${ }^{17}$ Control of imports or exports of goods that are suspected to be the result of violations of Intellectual Property Rights in Indonesia is one of the efforts to increase national economic growth by encouraging import or export activities to run according to fair trade practices by ensuring legal certainty of goods that have been protected by Intellectual Property Rights and implemented based on the spirit of active public participation (public awareness) and the State's obligation to protect Intellectual Property Rights. ${ }^{18}$

The position of DJBC as a supervisor of goods traffic both entering and leaving Indonesian territory, DJBC is required to control the import-export of goods resulting from violations in the field of IPR as a continuation of the ratification above of Indonesia regarding the provisions of border measure control/border enforcement contained in Article 51 to Article 60 the TRIPs Agreement, precisely implemented in Articles 54 through Article 64 of Law Number 17 of 2006 concerning Amendments (Chapter X): "Prohibition and Restrictions on Imports or Exports, Suspension of Imports or Exports of Goods resulting from Violation of Rights over Intellectual Property and Enforcement of Goods related to Terrorism and Transnational Crimes. " In this function, DJBC is expected to be able to act effectively to prevent IPR violations that cross customs areas (Border Cross Control). Law Number 10 of 1995 concerning Customs.

The Directorate General of Customs and Excise carries out this control function by deferring the release of imported / export goods from customs areas to provide opportunities for those entitled to trademark rights to take legal action. Suspension of the release of goods is done in two ways: First, the suspension of the release of imported (or export) goods based on a written

17 Djafar Albram, Implementasi Tata Kelola Kewenangan Bea Dan Cukai Di Bidang Hak Kekayaan Intelektual Di Indonesia, Jurnal Ilmiah Kebijakan Hukum, Volume 11 Number 1 Maret 2017, p. 78.

18 Yoga Mahardhita dan Ahmad Yakub Sukro, Perlindungan Hukum Hak Kekayaan Intelektual Melalui

Mekanisme "Cross Border Measure" Jurnal Ilmiah Ilmu Hukum QISTIE Volume 11 Number 1 Mei 2018, p. 97.

UNTAG LAW REVIEW (ULREV) 
order from the Head of the District Court at the request of the owner/holder of IPR by submitting sufficient evidence of IPR violations along with the placement of guarantees for risk (passive action procedure). Second, the suspension of the release of imported (or export) goods because of their position (ex officio) based on sufficient evidence of an IPR violation (active action procedure).

\section{Limitations in the Implementation of the Role of Customs for Brand Protection}

Limitations in the implementation of the role of customs in the field of Trademark are the unknown types of incoming and outgoing products that have certain brand identification, so customs authorities often wait to follow up on the discovery of products that are identified as violating trademark rights. The implementation of the supervisory function carried out by DJBC, especially in the field of brand rights at the beginning of its development, has limitations both in terms of technical implementation as well as in terms of the impact it causes. The supervision system by ensuring the truth element of customs notification and supervision of goods can clash with the function of the service system. Besides this, technically, there are several conditions that directly or indirectly can hamper the implementation of the existing surveillance system of brand rights. These conditions include the following:

1) The condition of Indonesia's geography to carry out effective physical supervision.

2) The development of the international trade system which continues to increase towards a more efficient and profitable.

3) Limited human resources and costs owned by DJBC in carrying out supervisory duties.

However, increasing the development of oversight systems that are too strict and rigid, on the contrary, can reduce or hinder service functions, namely an increase in the smooth flow of goods and documents and international trade. So that in order to effectively achieve its goals and mission DJBC is required to carry out both functions, namely the service and supervision functions, in a balanced manner without reducing the purpose and objectives of each function. Regarding the brand rights protection framework, the action or authority that can be carried out by DJBC is the action of 'temporary suspension of the release of imported or exported goods from customs areas' or what TRIPs calls 'suspension of release by customs'. The "border measurement" act by DJBC was considered effective enough to prevent violations of brand rights. The suspension action carried out at the 'exit' or 'entry point' in the Customs area can prevent goods that are alleged to violate trademark rights before the goods enter the commercial distribution channel in free areas, where prevention will be more complicated and costly.

It should be noted that although the DJBC official is a Civil Servant Investigator (PPNS) in cases of customs violations, the PPNS of Customs and Excise in the field of IPR do not have the authority of 'ex oficio' because of his position, the handling of his case is subsequently left to the Indonesian National Police (Polri) or PPNS Directorate General IPR, for further legal proceedings. Based on Law Number 17 of 2006 concerning Customs, matters that need to be considered regarding Customs involvement in implementing protection of a trademark or IPR rights by Customs and Excise can be implemented based on two reasons, namely:

1. Suspension of expenditure based on a written order from the Chair of the Local District Court / Local Commercial Court

Based on Article 54 of the Customs Law, in Indonesia, the request (by the owner or rightholder) is submitted to the Chairperson of the Local District Court. With the selection of the request line through this court, a written order from the Chair of the Local District Court is 
required for Customs and Excise Officials to carry out suspension of goods expenditure. The problem is that there are differences in the jurisdiction of the court that has the authority to set a temporary suspension (injunction) or examine IPR violations between the Customs Law (appointing a District Court) and the laws in the field of IPR (appointing a Commercial Court). So there are two possible alternatives that can be proposed:

a) Give authority.

To give authority to the Commercial Court to determine the injunction and to decide cases of IPR violations, with consideration as an effort to submit to the IPR regime in accordance with adage lex posterior derogate lex priori (the applicable law later overrides the previous law. The number of Commercial Courts, right holders can make efforts to hold the mechanism of suspension because of the position (ex oficio).

b) Keep giving authority

Continue to give authority to the District Court to determine the injunction and to decide cases of IPR violations, with consideration to accommodate the provisions in the Customs Law and to overcome the limited number of Commercial Courts compared to District Courts that are found in almost all borders of the DBJC.

In some countries, such requests are submitted to Customs and Excise without going through a court. The procedure for submitting requests to Customs and Excise in its implementation is far more effective than filing requests to the District Court because Customs and Excise can act directly based on data submitted by the owner or right-holder in his application. ${ }^{19}$

2. Suspension of Expenditures of Goods Due to Position (Ex-Officio Action)

The act of suspending the release of imported or exported goods may also be carried out because of a position by the Customs and Excise Official if there is sufficient evidence that the goods constitute or originate from the result of a trademark or copyright violation. Article 62 of the Customs Law does not describe the definition of "deferral due to position" and its scope. In the Elucidation of Article 62 of the Customs Law, it is only stated that this action is carried out only if there is sufficient evidence, and the aim is to prevent the circulation of goods that violate brands and copyrights that adversely affect the economy in general. Furthermore, it is stated that in the case of suspension due to a position, the full procedures as stipulated in the Trademark Law and the Copyright Act.

Based on this, DJBC's authority in terms of active action procedures needs to be given a strong foundation. Although the right holder does not object to violations of his rights, the legal process must continue to be carried out on the basis of his violation of the IPR, not on the complaint from the holder. Starting from that, it is necessary to take some efforts to add provisions in the said regulation, in the form of the possibility of collaboration between the right holder and $\mathrm{DJBC}$, that in the case of active action procedures $\mathrm{DJBC}$ can enforce export and import goods as a result of IPR violations. Or the other way is possible for the duty of the State, DJBC has the right to temporarily interrogate the goods without guarantee until it is proven that the person really violated the IPR.

19 Ade Maman Suherman, "Penegakan Hukum atas Hak Kekayaan Intelektual di Indonesia," Jurnal Hukum Bisnis, Volume 23 Number 1, 2004, p. 86-91. 
It should also be considered to authorize the Customs and Excise Official (ex-officio) to confiscate and destroy items that violate IPR or order the importer to send the goods back. In Article 63 of the Law on Amendments to the Customs Law, the above exceptions are stipulated, whereby the suspension of the release of goods suspected to be the result of the infringement of IPRs, does not apply to the following types of goods: passenger luggage, the crew of transport facilities, border crossers or items sent by post or deposit services. The condition is that the goods are not intended for commercial purposes.

In the context of improving the smooth flow of goods, the principle of examination of exported goods is document examination, whereas physical inspection is only carried out in certain matters. For imported goods, physical inspection is only carried out selectively based on risk management. Physical inspection of imported goods is only carried out on the importation of goods, which are categorized as having high risks, for example, high import duties, dangerous for the State and society, or importing by importers who have poor records. As a consequence of government policy as above, there is relatively little opportunity for Customs and Excise to carry out active action procedures. With relatively limited opportunities to act actively, the Customs and Excise Office has increased other efforts in order to streamline the task of controlling the import-export of goods resulting from IPR violations. For example, conducting special education in the field of IPR for officials and officials, and building a database system that can access databases of developed countries and WTO so that it is easy to obtain information about data on ownership or violations in the field of IPR.

\section{CONCLUSION}

Based on the issues examined regarding the legal protection of the rights to foreign brands according to Law Number 10 of 1995 Concerning Customs, the conclusion that constitutional protection of registered trademarks is related to the Customs Law is only concerned with the issue of protection of the control of the import or export of the goods produced violation of trademark rights, so that with the customs law, through the Customs apparatus it will get a positive value in the form of prevention of entry or entry of products resulting from violations of trademark rights from Indonesia or Indonesia.

\section{REFERENCES}

Djuhaendah Hasan, Lembaga Jaminan Kebendaan Bagi Tanah dan Benda Lain Yang Melekat Pada Tanah Dalam Konsepsi Penerapan Asas Pemisahan Horisontal, Citra Aditya Bakti, Bandung, 1996.

Dwi Rezki Sri Astarini, Penghapusan Merek Terdaftar, Alumni, Bandung, 2009.

Eddy Damian, Hak Kekayaan Intelektual (Suatu Pengantar), Alumni, Bandung, 2003.

HarisMunandar, Mengenal HaKI, Hak Cipta Paten danMerek Serta Seluk Beluknya, Erlangga, Jakarta, 2008. 
Julius Rizaldi, Perlindungan Kemasan Produk Merek Terkenal Terhadap Persainga Curang, Alumni, Bandung, 2009.

Sudargo Gautama, Hak Merek Dagang Menurut Perjanjian TRIPs-GATT dan UndangUndang Merek RI, Citra Aditya Bakti, Bandung, 1994.

Sudargo Gautama danRizwantoWinata, Pembaharuan Hukum Merek Indonesia (Dalam rangka WTO, TRIPs), Citra Aditya Bakti, Bandung, 1997.

Tim Lindsey, Eddy damian, dkk, Hak Kekayaan Intelektual Suatu Pengantar, Asian Law Group Pty Ltd dan Alumni, Bandung, 2002.

Ade MamanSuherman, "Penegakan Hukum atas Hak Kekayaan Intelektual di Indonesia," Jurnal Hukum Bisnis, Volume 23 Number 1, 2004.

DirektoratJenderal Bea dan Cukai, "Peranan Bea dan Cukai Dalam Perlindungan Hak atas Kekayaan Intelektual," Paper presented at Training Course on Intellectual Property Rights, Jakarta, 24-28 Mei 2004.

Djafar Albram, Implementasi Tata Kelola Kewenangan Bea Dan Cukai Di Bidang Hak Kekayaan Intelektual Di Indonesia, Jurnal Ilmiah Kebijakan Hukum, Volume 11 Number 1 Maret 2017.

Edi Santoso, Penegakan Hukum terhadap Pelanggarang Merek Dagang Terkenal Melalui Perang Kepabeanan sebagai Upaya Menjaga Keamanan dan Kedaulatan Negara,Jurnal Rechts Vinding, Volume 5, Number 1, April 2016.

Yoga Mahardhita dan Ahmad Yakub Sukro, Perlindungan Hukum Hak Kekayaan Intelektual Melalui Mekanisme "Cross Border Measure" Jurnal Ilmiah Ilmu Hukum QISTIE Volume 11 Number 1 Mei 2018.

Isu Plastik, Beras Organik Kini Diburu Warga, Liputan 6, 30 Mei 2015, http://tv.liputan6.com/read/2242573/isu-plastik-beras-organik-kini-diburu-warga.

Kemdag Tertibkan 726 Jenis Barang Ilegal, Suara Pembaharuan, 23April2013, http://sp.beritasatu.com/ekonomidanbisnis/kemdag-tertibkan-726-jenis-barangilegal/34399.

Produk Ilegal Datang Dari China \& Malaysia BPOM Tangani 51 Kasus, Hukuman Tak Bikin Jera, 30 September 2012, http://www.rmol.co/read/2012/09/30/79937/Produk-IlegalDatang-Dari-China-\&-Malaysia-, 